\title{
A CONCEPTUAL MODEL FOR THE ORIGINS OF GEOTHERMAL AND VOLCANIC ACTIVITY IN THE NORTH ISLAND OF NEW ZEALAND
}

\author{
ALEX MCNABB $^{1}$ \\ (Received 21 November, 2007; revised 23 February, 2009)
}

\begin{abstract}
The current geothermal and volcanic activity in the North Island of New Zealand is explained as a consequence of Pacific and Australian plate interactions over the last 20 million years. The primary hypothesis is that the Kermadec subduction zone has for the last 20 million years or more been retreating in a south-easterly direction at about five centimetres per year. It is surmised that this motion and interaction with another subduction zone almost at right angles to it under the North Island resulted in plate tearing due to the incompatibility of the plate geometry where these subduction zones interacted. The nature and consequences of this plate tearing are partially revealed in published maps of the plate currently under the North Island. If the subducted parts of this plate, as shown in Eiby's maps, [G. A. Eiby, "The New Zealand sub-crustal rift", New Zeal. J. Geol. Geophy. 7 (1964) 109-133] are straightened, then the plate edge lies on a curve giving a rough picture of their position before being torn and subducted by the Kermadec trench motion. This map of the tear suggests the shape of the edge of a missing plate segment torn from the plate, and implies a rotation of the upper North Island, clockwise approximately 20 degrees, about a point just south of the Thames estuary. A consequence of this plate tearing is that the solid retreating crustal wave generating magma pressure beneath the crest of the solid wave has the potential to inject significant basaltic magma into the crust through the tears. These intrusive magma fluxes have the ability to generate geothermal fields and rhyolitic lavas from crustal melts. This could explain the geothermal activity along the Coromandel peninsula five to seven million years ago, the ignimbrite outcrops about Lake Taupo and the current geothermal and volcanic activity stretching from Taupo to Rotorua.
\end{abstract}

2000 Mathematics subject classification: primary 74C99; secondary 52C35, 74A45.

Keywords and phrases: crustal heat and mass flow, geothermal energy, volcanology.

\section{Introduction}

The aim of this paper is to present a conceptual model for the origins of geothermal and volcanic activity in the North Island of New Zealand during the last 20 million years.

${ }^{1} 39$ Palmyra Way, Halfmoon Bay, Auckland, New Zealand; e-mail: a.mcnabb@xtra.co.nz.

(C) Australian Mathematical Society 2009, Serial-fee code 1446-1811/2009 \$16.00 
The ideas and concepts are presented on the understanding that science is the most successful of all human endeavours in that rare category of "nonbelief" activities and new ideas are readily accepted for testing and evaluation. Nothing in the physical world is ever definitively established and potential models for nature's weird and wonderful activities need to be laid on the table for evaluation, modification and possible rejection by all the scientific disciplines. The topic discussed here is a difficult interdisciplinary one requiring the geological, volcanological, physical, chemical and applied mathematical knowledge and skills that could only be brought to bear on it by a large dedicated interdisciplinary team with an in-depth knowledge of all research into the geothermal, volcanic and plate tectonic activity in the North Island of New Zealand.

In the 1950s and 1960s, the New Zealand Department of Scientific and Industrial Research (DSIR), in collaboration with the New Zealand Ministry of Works, assessed and developed the geothermal energy potential of the Wairakei geothermal field of New Zealand, and produced a power plant providing a quarter of the electrical energy consumed in the North Island at that time at a cost cheaper than any other plant in the country. A subsidiary outcome of this research was an interdisciplinary perspective of the geothermal activity in the North Island of New Zealand and an appreciation of the history and extent of the rhyolitic volcanism associated with it.

In this paper, the current geothermal and volcanic activity in the North Island of New Zealand is portrayed as part of a process involving Pacific and Australian plate interactions over the last 20 million years. The primary hypothesis is that the Kermadec subduction zone has for the last 20 million years or more been retreating in a south-easterly direction at about $5 \mathrm{~cm}$ per year. Data relating to this roll-back are presented in a recent paper [3]. It is surmised that this motion and interaction with another subduction zone almost at right angles to it under the North Island resulted in plate tearing due to the incompatibility of the plate geometry where these subduction zones interacted. The nature of this plate tearing is partially revealed in the maps of the plate currently under the North Island produced by Eiby [2] using earthquake records and estimated epicentres deep under the North Island as summarized in his Figure 11.

An earthen crust $10 \mathrm{~km}$ thick submerged in a molten environment would be brought to near thermal equilibrium in a time $\tau$, say, which can be estimated as follows. Since heat absorption $(T)$ is governed by the heat conduction equation

$$
\frac{\partial T}{\partial t}=K \nabla^{2} T
$$

and the thermal diffusivity $K$ is greater than $1 \times 10^{-6} \mathrm{~m}^{2} \mathrm{~s}^{-1}$ in the temperature range of interest, $\tau$ is approximately $a^{2} / K$ for $a$, the crust half-thickness, equal to $5 \mathrm{~km}$. This gives a time of about 1 million years ( $1 \mathrm{Ma}$ ). After 10 million years we can expect the temperature variations to be negligible. Hence there is a time limit of this order on the potential for exploring former plate activity using earthquake data, because the rock will no longer be brittle enough to support fracturing. 
Figure 1 is constructed by combining elements from Figures 8 and 11 of Eiby [2]. The original plate material, shown bent and subducted in these diagrams, we assume was roughly planar before its interaction with the retreating Kermadec trench. If we straighten the bent, subducted parts of this crust back into a horizontal plane, we find that their end points at the deepest parts of Eiby's maps of the subduction zone lie on a curve A1-B1-C1-D1-E1-F1, shown in Figure 1, giving at the top end a rough picture of their position before being subducted and torn by the Kermadec trench motion. This curve is assumed to be a plate tear in response to interaction with an early subduction zone under Northland. A1-B1-C1 represents the eastern edge and C1-B2-A2 the western edge of a torn plate segment representing this early subduction zone, both in the position occupied $20 \mathrm{Ma}$ before the segment was torn off. The eastern edge A1-B1 would have been the start of its subduction under Northland, making plate tearing the only option as the Kermadec trench moved south. This would require the upper part of the North Island to be rotated clockwise about 20 degrees from its present position.

It is conceivable that the subductive motion of such a torn segment A1-B1-C1B2-A2 has the potential to reorientate the topography above it. This could explain an observation [1] that magnetism frozen in the basalts north of Auckland 10 million years or more ago are not aligned with the magnetic north pole and suggest a significant rotation of the topography over that time scale. This and subsequent palaeomagnetic studies have been described and assessed in a Ph. D. thesis [5] and an estimate of 25 degrees anticlockwise rotation over the last 10 million years is suggested, which is compatible with the rotation suggested by the early plate tearing in Figure 1.

A second aspect of this plate tearing is that the solid retreating crustal wave seen today as the Kermadec trench, moving south-east at about $5 \mathrm{~cm}$ per year, generates magma pressure beneath the crest of the solid wave with the potential to produce significant basaltic magma flows into the Northland crust through the tears. These intrusive magma fluxes have the ability to generate geothermal fields and rhyolitic lavas from crustal melts. This could explain the geothermal activity along the Coromandel peninsula five to seven million years ago, the ignimbrite outcrops along the highways heading to Lake Taupo and the current geothermal and volcanic activity stretching from Taupo to Rotorua. This magma flux from under the retreating crustal wave could also generate a large magma pool under the Taranaki crust which, together with subducted torn plate segments, could explain the large gravity anomaly in this area (see [2, Figure 14, Page 126]) and the volcanic activity at Mt Egmont (Taranaki). The spacing of the geothermal fields from Lake Taupo to Rotorua and beyond of roughly $7 \mathrm{~km}$ also suggests a magmatic intrusion of similar depth stretching under all the 20 or so geothermal fields.

This magmatic intrusion over a period of 300000 years would also account for the crustal thinning from 30 to $20 \mathrm{~km}$ since the same heat flux through the geothermal fields as measured today has the capacity to melt $10 \mathrm{~km}$ of crust underneath it over this time scale and naturally a hot molten intrusion could be expected to send heat equally in both directions. This melt could also have been responsible for generating 


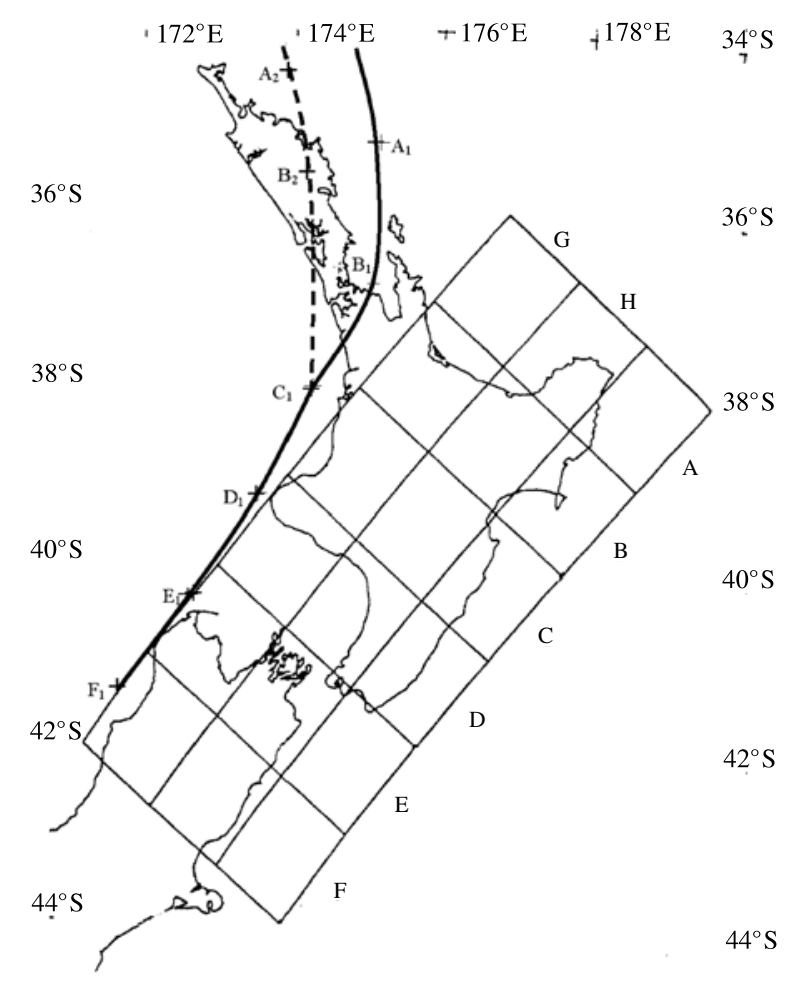

FIGURE 1. Diagram of torn ocean plate segment positioned as it might have been 20 million years ago. The solid line A1-B1-C1 is the tear generated by Kermadec trench motion and the broken line C1-B2-A2 its western plate edge before tearing.

the $3 \mathrm{~km}$ of rhyolitic ash found covering the geothermal region today. All this raises an interesting question as to why such a magmatic intrusion chooses a depth of $7 \mathrm{~km}$. Is this a consequence of the gas content of the intrusive magma causing the basalt to start frothing at this depth and generate fractures in the crust?

Recent palaeomagnetic measurements in the Bay of Plenty and east coast from sediments of known ages (up to about $3 \mathrm{Ma}$ ) show that the east coast is rotating clockwise at quite a fast rate-between 1 and 4 degrees per million years. This possibly corresponds to a velocity of $2 \mathrm{~cm}$ per year at East Cape in the direction of the retreating trench. This in itself is strong confirmation of trench motion and interaction with the east cape since plate subduction on the northern side would surely cause anticlockwise rotation. There are several publications on this topic [4, 6, 8], and recent GPS results are in [7].

\section{Acknowledgements}

This paper was presented at a memorial conference in honour of the work of Steve White at the Applied Mathematics Division in Wellington on 29 August 2007. It was 
a great pleasure to meet with many former colleagues at the conference after having retired from applied mathematical activities some years ago.

\section{References}

[1] D. S. Coombs and T. Hatherton, "Palaeomagnetic studies of Cenozoic volcanic rocks in New Zealand", Nature 184 (1959) 883-884.

[2] G. A. Eiby, "The New Zealand sub-crustal rift", New Zeal. J. Geol. Geophys. 7 (1964) 109-133.

[3] N. Mortimer, R. H. Herzer, P. B. Gans, C. Laporte-Magoni, A. T. Calvert and D. Bosch, "Oligocene-Miocene tectonic evolution of the South Fiji Basin and Northland Plateau, SW Pacific Ocean: evidence from petrology and dating of dredged rocks", Mar. Geol. 237 (2007) 1-24.

[4] T. C. Mumme, S. H. Lamb and R. I. Walcott, "The Raukumara paleomagnetic domain: constraints on the tectonic rotation of the east coast, North Island, New Zealand, from paleomagnetic data", New Zeal. J. Geol. Geophys. 32 (1989) 317-326.

[5] D. J. Robertson, "Palaeomagnetism and geochronology of volcanic in the Northern North Island, New Zealand", Ph. D. Thesis, University of Auckland, New Zealand, 1983.

[6] R. I. Walcott and T. C. Mumme, "Paleomagnetic study of the Tertiary sedimentary rocks from the east coast of the North Island, New Zealand", Report 189, Department of Scientific and Industrial Research, New Zealand, Geophysics Division, 1982.

[7] L. M. Wallace, R. J. Beavan, R. McCaffrey and D. J. Darby, "Subduction zone coupling and tectonic block rotations in the North Island, New Zealand", J. Geophys. Res. Solid Earth 109 (2004) B12406, doi:10.1029/2004JB003241.

[8] I. C. Wright and R. I. Walcott, "Large tectonic rotation of part of New Zealand in the last 5 Ma", Earth Planet. Sci. Lett. 80 (1986) 348-352. 